\title{
Heavy Seasonal Grazing on Central Arizona Piñon-Juniper Rangeland: Risky Business?
}

\author{
By Doug Tolleson
}

\section{On the Ground}

- This piñon-juniper rangeland in central Arizona experienced heavy seasonal (late-spring/earlysummer) grazing, but with above average, welltimed and evenly distributed precipitation for the time of year; both cool- and warm-season native grasses recovered.

- If this study had been conducted on rangeland that was typically more heavily grazed, and more susceptible to erosion, and done later in the growing season, the risk of exceeding targeted end-of-season grazing utilization would have been greater.

- Planning for, or reacting to, grazing utilization that exceeds targeted levels should take site-specific risk factors into consideration.

Keywords: grazing, utilization; risk, western wheatgrass, sideoats grama, piñon-juniper.

Rangelands 36(3):12-17

doi: 10.2111/Rangelands-D-14-00001.1

(C) 2014 The Society for Range Management

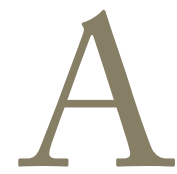

$s$ a rangeland extension specialist, I see the land outside my windshield as I drive across the countryside differently than most. Things such as body condition of animals, what plants are greening up, who got a rain, or how much water is in the creek catches my eye. I am also always on the lookout for "teachable moments"; events or experiences that occur out on rangelands that I can turn into a study, presentation, or publication to share with others. So it is not too surprising that one day in late June of 2012, I noticed that heavy (greater than 60\%) grazing utilization ${ }^{1}$ had occurred on a 520 -acre piñon-juniper (approximately 5,000-foot elevation) pasture in the Mogollon Rim country of central Arizona (Fig. 1). It turns out that grazing by cattle (approximately 350 cow-calf pairs) had occurred 2 weeks earlier. The pasture is long and narrow, running northwest to southeast and has one water source (earthen tank) at the southeast end. This area had received 2.83 inches of precipitation from January to April and no measurable rain in May and June (Table 1). The most recent 10-year averages for these periods measured by a rain gauge approximately 3 miles northeast are $6.85 \pm 1.5$ and $0.49 \pm 0.21$ inches respectively (Table 1 ). This general area of the state was in the severe drought category at the time. ${ }^{2}$ Due to the drought conditions, I wanted to observe and document perennial range grass regrowth in this pasture. Because our Arizona summer monsoon precipitation is often highly variable in space and time, I also wanted to assess the potential risk to near-term forage production caused by a one-time heavy grazing event in this piñon-juniper rangeland. ${ }^{3}$

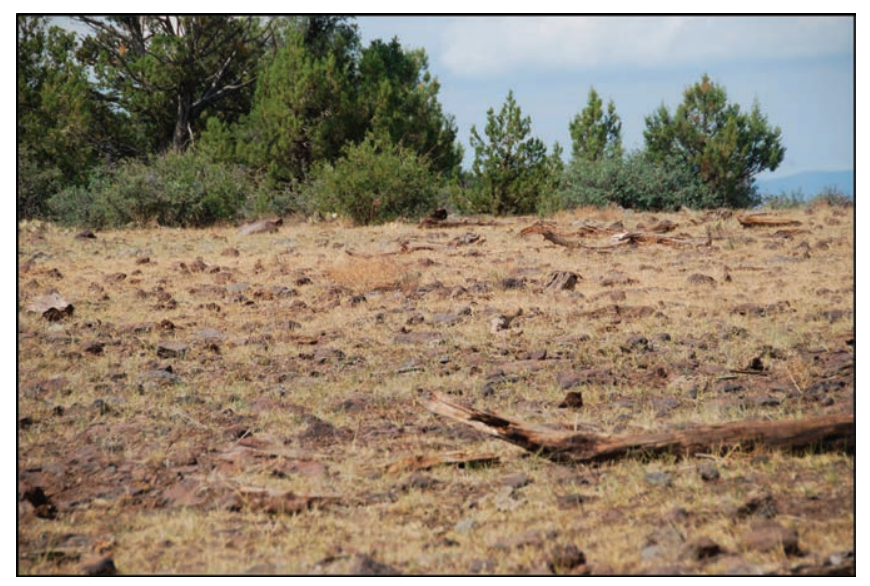

Figure 1. Heavily utilized piñon-juniper rangeland in the Mogollon Rim area of central Arizona. 
Table 1. Monthly precipitation (inches) for Mogollon Rim (Arizona) study pasture

\begin{tabular}{|c|c|c|c|c|c|c|c|c|c|c|c|c|}
\hline & 2002 & 2003 & 2004 & 2005 & 2006 & 2007 & 2008 & 2009 & 2010 & 2011 & 2012 & $\begin{array}{c}\text { 10-year } \\
\text { Avg }^{*}\end{array}$ \\
\hline January & 0.16 & 0.55 & 1.46 & 5.51 & 0.20 & 1.14 & 6.30 & 0.67 & 8.07 & 0.98 & 0.39 & 2.50 \\
\hline February & 0.00 & 6.81 & 2.09 & 5.83 & 0.00 & 2.17 & 2.76 & 2.32 & 2.76 & 2.76 & 0.35 & 2.75 \\
\hline March & 0.59 & 3.43 & 0.16 & 2.17 & 1.69 & 0.98 & 0.04 & 0.00 & 2.24 & 0.83 & 1.30 & 1.21 \\
\hline April & 0.59 & 0.67 & 1.54 & 2.76 & 0.51 & 0.20 & 0.00 & 0.31 & 0.35 & 0.87 & 0.79 & 0.78 \\
\hline May & 0.00 & 0.20 & 0.00 & 0.00 & 0.24 & 0.08 & 0.75 & 1.93 & 0.00 & 0.75 & 0.00 & 0.40 \\
\hline June & 0.00 & 0.00 & 0.00 & 0.31 & 0.20 & 0.08 & 0.55 & 0.28 & 0.00 & 0.00 & 0.00 & 0.14 \\
\hline July & 1.69 & 1.14 & 1.57 & 2.60 & 4.76 & 6.61 & 1.89 & 0.67 & 3.86 & 3.35 & 5.16 & 2.81 \\
\hline August & 0.87 & 3.78 & 1.77 & 2.99 & 3.58 & 1.42 & 4.37 & 0.91 & 2.44 & 1.81 & 3.07 & 2.39 \\
\hline September & 6.81 & 1.18 & 4.45 & 0.12 & 1.65 & 0.87 & 0.16 & 1.77 & 0.59 & 2.17 & 0.83 & 1.98 \\
\hline October & 3.03 & 0.00 & 5.12 & 1.46 & 2.24 & 0.04 & 0.28 & 0.00 & 2.05 & 1.73 & 0.79 & 1.60 \\
\hline November & 2.17 & 1.61 & 2.68 & 0.12 & 0.16 & 1.81 & 2.40 & 0.12 & 0.79 & 3.11 & 0.79 & 1.50 \\
\hline December & 1.97 & 0.94 & 3.70 & 0.00 & 0.98 & 4.09 & 5.12 & 2.52 & 4.17 & 2.72 & 2.56 & 2.62 \\
\hline Total & 17.88 & 20.31 & 24.54 & 23.87 & 16.21 & 19.49 & 24.62 & 11.50 & 27.32 & 21.08 & 16.03 & 20.68 \\
\hline
\end{tabular}

\section{An Opportunistic Experiment \\ What I Did}

After my initial observation, I returned to the pasture in mid-July of 2012 to collect stubble height and grazing utilization data using the height:weight method as described by Smith et al. ${ }^{1}$ I chose to monitor a cool season (western wheatgrass; Pascopyrum smithii) and a warm season (sideoats grama; Bouteloua curtipendula) grass. As luck would have it, this area received approximately 5 inches of rain (Table 1 ) in the interim, and thus some regrowth had likely occurred since my initial observation. I conducted 10, 25-point utilization transects distributed approximately 300 yards apart across the length of the pasture. At each transect, I recorded the starting and ending coordinates with a hand-held GPS. At each pace along a transect, the height of the nearest western wheatgrass or sideoats grama plant was recorded to the nearest 0.5 inch and entered into a grazing utilization spreadsheet on a touch screen tablet computer. I clipped one $0.25-\mathrm{m}^{2}$ quadrat at a randomly chosen point along each transect to de- termine standing crop. Clipped samples were dried 48 hours in a forced-air oven at $140^{\circ} \mathrm{F}$ and weighed to determine dry matter. I also took a series of photographs that represented the general conditions in the pasture. The same procedures were repeated for the same transects in mid-September 2012 and early May 2013. Also in May, I clipped three samples of western wheatgrass and sideoats grama in an adjacent pasture which had been grazed in the late fall of 2012 to compare to three samples of each species that had been clipped in the study pasture. These clipped samples were analyzed for crude protein and total digestible nutrients by near infrared spectroscopy at a commercial laboratory. Differences in stubble height, estimated grazing utilization, and forage quality between species and dates were determined using analysis of variance procedures. ${ }^{4}$

\section{What I Found Out}

Monthly precipitation recorded for 2002 through 2012 in the study area is recorded in Table 1 , and the grazing uti- 
lization and stubble height values I measured are reported in Table 2. Stubble heights (on a per-transect basis) were generally less than 3 inches for both species observed in July and had reached 6 and 16 inches by September for western wheatgrass and sideoats grama, respectively. The following May, these values were approximately seven and six inches respectively. Not surprisingly, grazing utilization (on a per-transect basis) followed a similar pattern and ranged from $45 \%$ to $68 \%$ (mean $62 \pm 2 \%$ ) in July, $8 \%$ to $32 \%$ (mean $22 \pm 2 \%$ ) in September, and $17 \%$ to $29 \%$ (mean $23 \pm 1 \%$ ) in
May. Observed utilization for western wheatgrass was approximately five times that of sideoats grama in September as compared to approximately two times greater in May of the next year.

Dry matter standing crop is illustrated in Figure 2. The overall average increased from approximately 100 pounds/ acre in July to approximately 1,000 pounds/acre by September. The following May, there was approximately 500 pounds/acre of dry matter standing crop. Percent crude protein and total digestible nutrients (Table 3) were statistically

Table 2. Effect of date and forage species on stubble height and estimated grazing utilization on piñon-juniper rangeland in central Arizona*

\begin{tabular}{|l|c|c|c|c|c|}
\hline & \multirow{2}{*}{ Date } & \multicolumn{2}{|c|}{ Stubble height (inches) } & \multicolumn{2}{|c|}{ Utilization (\%) } \\
\hline & Species & Mean & SEt & Mean & SEt \\
\hline 13 July 2012 & PASM & 2.69 & 0.22 & 56.84 & 2.62 \\
\hline 13 July 2012 & BOCU & 3.01 & 0.30 & 66.96 & 1.74 \\
\hline 3 September 2012 & PASM & 6.44 & 0.48 & 36.59 & 2.40 \\
\hline 3 September 2012 & BOCU & 16.47 & 0.66 & 7.06 & 1.50 \\
\hline 4 May 2013 & PASM & 6.95 & 0.28 & 26.12 & 1.48 \\
\hline 4 May 2013 & BOCU & 5.62 & 0.26 & 14.60 & 1.76 \\
\hline
\end{tabular}

*Date, species, and the date $\times$ species interaction; $P<0.05$.

+Standard Error of the Mean.

PASM indicates Pascopyrum smithii (western wheatgrass); BOCU, Boutelua curtipendula (sideoats grama).

Table 3. Effect of pasture location on forage quality in two Arizona range grasses

\begin{tabular}{|l|l|l|l|l|l|l|}
\hline \multirow{2}{*}{ Species } & Treatment & N & \multicolumn{3}{|c|}{ CP } & \multicolumn{2}{|c|}{ TDN } \\
\cline { 3 - 7 } & Study & 3 & 10.83 & 0.67 & 58.13 & SEt \\
\hline PASM & Adjacent & 3 & 10.20 & 0.64 & 58.50 & 1.61 \\
\hline PASM & Study & 3 & 5.93 & 0.64 & 48.77 & 1.39 \\
\hline BOCU & Adjacent & 3 & 4.83 & 0.32 & 43.27 & 1.71 \\
\hline BOCU & & & & Sean & & \\
\hline
\end{tabular}

†Standard Error of the Mean.

CP indicates crude protein; TDN, total digestible nutrients; PASM, Pascopyrum smithii (western wheatgrass); BOCU, Boutelua curtipendula (sideoats grama). 


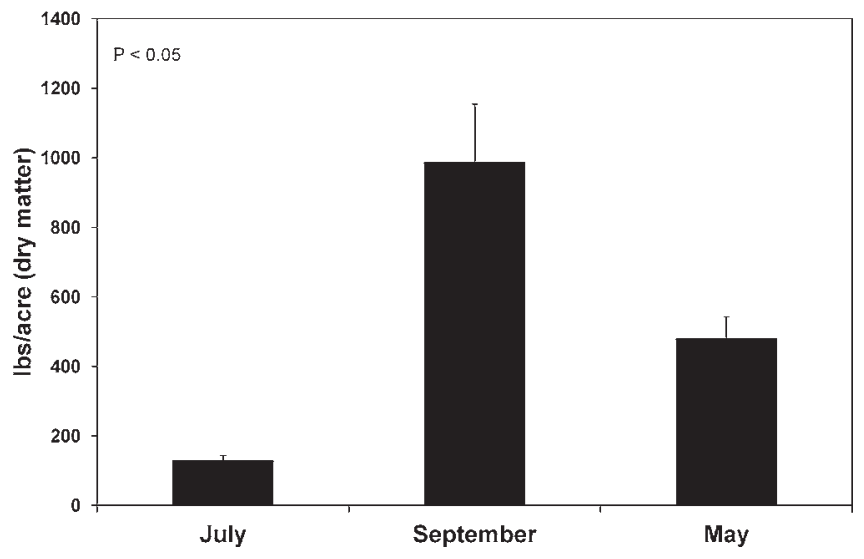

Figure 2. The effect of date on standing crop measured in pinon-juniper rangeland in central Arizona.

greater $^{\mathrm{i}}$ for western wheatgrass $(10.5 \pm 0.4 ; 58.3 \pm 0.8$, respectively) than for sideoats grama $(5.4 \pm 0.4 ; 46.0 \pm 1.6$, respectively). Pasture (i.e., study versus adjacent) did not generally significantly affect forage quality, but for sideoats grama, percent crude protein was numerically greater $(5.9 \pm 0.6$ versus $4.8 \pm 0.3$, respectively) and total digestible nutrients tended $\mathrm{d}^{\mathrm{ii}}$ to be greater ( $48.8 \pm 1.4$ versus $43.2 \pm 1.7$, respectively) in the study pasture than in the adjacent pasture.

\section{So What Does This Mean?}

Hot, dry winds and no rain in late May and early June 2012 had turned much of the western wheatgrass in the study area from green to brown, bypassing the typical interim "blue" stage..$^{5}$ Other range plants and water supplies were showing similar effects of our region being in the severe drought category as previously mentioned. Fortunately, timely monsoon rains after a drier than average winter and spring led to forage growth and recovery in the study pasture (Fig. 3). More importantly, perhaps, is that most of this rain fell in storms that were generally more widely distributed and less intense than "normal" precipitation from the convective storms frequently experienced during this time of year. Had less moisture fallen during late summer or if the storms had been smaller and more intense, the results of this study would have been different; i.e., less regrowth and more erosion, respectively. In the previous 10 years at this location, April, May, and June experienced below-average rain 6 years out of 10. In particular, five Mays and six Junes often had no rain, just like in 2012. The summer monsoon (July, August, September) also had less than average rain 6 years out of 10, but had no instances of no rainfall. So although it is not unusual for our part of the world to be dry in early summer and wet by fall, a dry early summer followed by less than average (or late) monsoon precipitation happens about $50 \%$ of the time (Table 1 ). Thus, while it is my observation that most of us in the range management or livestock pro-

$$
{ }^{i} P<0.05 \text {. }
$$$$
\text { ii } P<0.07 \text {. }
$$

fessions tend to be optimistic when it comes to rain, experience tells me that we should err on the side of caution and evaluate management risks and alternatives to plan for contingencies that don't always include fortuitous precipitation. ${ }^{6,7}$

\section{Risk Factors}

Matching forage supply and demand on extensive rangelands is challenging during good times; it becomes more difficult during drought. The margin of error is smaller. A manager might have forage but not water, water but not forage, or might not have either very well distributed. Expeditious liquidation of livestock inventory or wildlife harvest might not always be practical. Greater than planned utilization sometimes occurs even in well-managed operations. High levels of herbivory, in space and time, also occur in natural or extensively managed ecosystems. ${ }^{8,9}$ Resilience is a term often used in ecology, and in general refers to either the ability of an ecosystem to return to "normal," or to a site that requires a great deal of disturbance to change from its' current state. ${ }^{10}$ Infrequent occurrences of heavy to severe grazing are usually not cause for drastic changes in management. However, understanding the risk and potential consequences of these events (i.e., How erosion-prone is this site? How long will it take to recover if I am wrong??) is important for sustainable range and livestock management.

Although heavy grazing did in fact occur on the study site, three factors other than rain reduced the risk of soil and forage loss to the enterprise in this instance. First, this event occurred in a small pasture that is typically used to move animals between larger pastures. It is not grazed every year and most often at light ( 20\%) to moderate $(\sim 40 \%)$ seasonal levels. Second, grazing occurred after the spring growing season for cool-season grasses and prior to the main summer growing season for warm-season grasses. Livestock did not re-enter the pasture that year. There was time for recovery to occur. And third, this area is relatively flat (3\% to 5\% slope) and is classified as a moderately deep cobbly clay loam that is reasonably well armored with $20 \%$ to $50 \%$ rock cover. Various sites $^{3}$ within the area are classified as slight to moderately susceptible to erosion and shrink-swell or piping characteristics can increase erosion potential if adequate ground cover is not maintained. ${ }^{3}$ I did observe instances of soil and litter movement, but these were minimal and found within the heavier tree (Juniperus spp.) cover.

\section{Measuring Utilization}

One observation I found informative was the pattern of utilization recorded between species at each sampling period. For instance, in July, after the main spring western wheatgrass growth period and between spring and summer sideoats grama growth periods, observed utilization was similar and high for both. Then in September, as expected, end-of-season utilization was much lower for sideoats grama than for western wheatgrass. The following spring, with what would have been predominately elk (Cervus elaphus) grazing prior to 


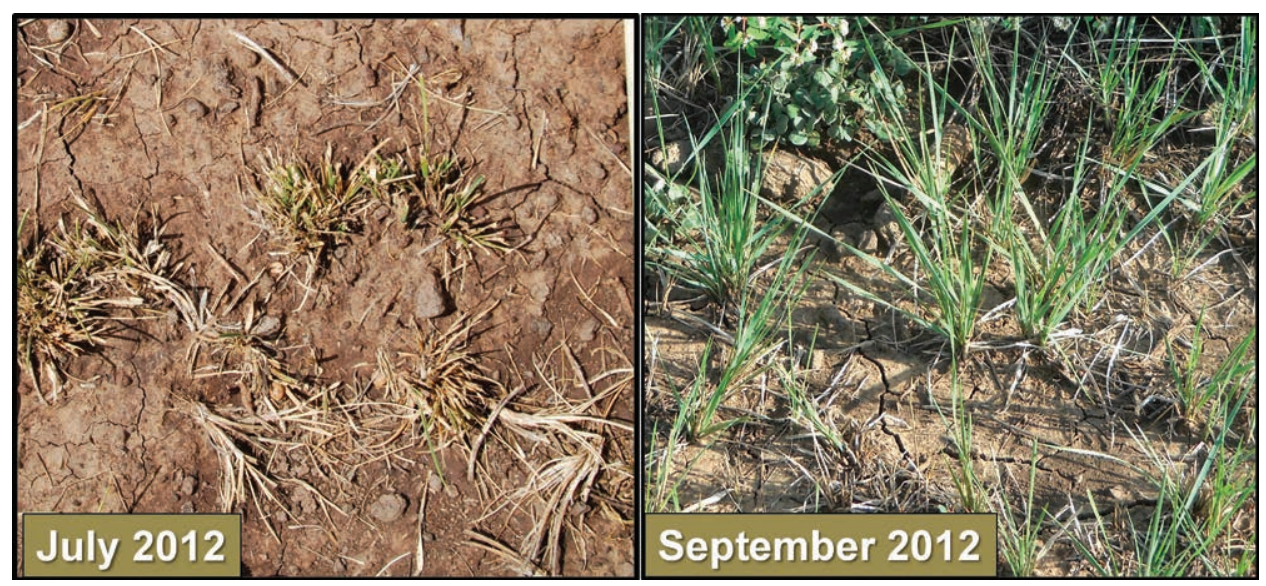

Figure 3. Typical utilization observed in July versus September 2012.

cattle (with the exception of small numbers of stray cattle), utilization was higher for western wheatgrass than for sideoats grama. I thought it was also interesting that compared to the fall, western wheatgrass utilization in May was lower, whereas the opposite was true for sideoats grama. This area had above-average rain over the winter but no rain in April 2013. Even though the western wheatgrass was already showing blue color in May, the nutrient quality was still greater than that for sideoats grama. In an earlier study conducted in this same general area, ${ }^{11}$ elk selected summer diets that were composed of approximately $60 \%$ grass. Crude protein content $(\sim 11 \%)$ of elk summer diets in the previous study was comparable to that in the clipped western wheatgrass samples in the current study.

Typical end-of-season grazing utilization guidelines for public land leases in the southwestern United States are usually between $30 \%$ and $40 \%$. Productivity within a given site and year, degree of seasonal utilization, and timing relative to the growing season all interact to affect conditions at the end of the growing season when utilization is evaluated for compliance. An excellent illustration of this concept is found in Smith et al. ${ }^{12}$ who state that:

\section{Seasonal utilization is the percentage of the forage produced in the current growing season to date of measurement that is removed by grazing. This percentage is different from [(end of season)] utilization because it does not account for subsequent growth of either the ungrazed or grazed plants. Seasonal utilization measured early in the growing season has no consistent relationship to [(end of season)] utiliza- tion based on total production. As the growing season pro- gresses, the difference between the two measurements is re- duced because the time available for regrowth diminished.}

These authors provided an example using data on Thurber's needlegrass (Achnatherum thurberianum) in which plants were clipped to 1-inch stubble height at progressive stages of growth, and utilization measured at each stage versus the end of the growing season. Percent utilization values for seasonal versus end-of-season were 80 and 17 at the preboot stage, 92 and 48 at boot, and both were 96 at the seed shatter stage.

I have read grazing management plans that state something to the effect that "When grazing utilization in a pasture reaches $40 \%$, livestock will be moved." One can see from the previous discussion and results of the current study that such rigidity isn't always practical or advisable. Utilization can certainly inform these types of decisions but should be evaluated in the context of, and along with, such knowledge as status of water and grass in the next pasture, where you are in the growing season, and what type of year you are having. In a given year, $40 \%$ might be too much, too little, or just right. There has been much discussion within the range profession on how to properly obtain and apply utilization measurements. ${ }^{12,13}$ There is documented and anecdotal evidence of misuse. These occur to the extent that I know of experienced range managers and scientists who feel that measuring utilization is not very useful, especially when compared to long-term trends, for instance. Although I understand their apprehension, my perspective, coming from an animal management background, is that utilization is one of the key measurements to inform sustainable range management. This is where the "plant-animal interface" happens. Where animals, domestic and wild, large and small, and charismatic and not so charismatic, obtain nutrition and shelter. Where management happens. For example, a report by $\mathrm{Meen}^{14}$ on forage quality of clipped range plants in the Arizona Strip showed that protein and energy were greater in light (30\%) than moderate $(60 \%)$ or heavy $(90 \%)$ utilization simulations. Utilization records can thus inform the short-term animal management decision making process as well as help in the interpretation of long-term ecological trends.

\section{Summary}

Overgrazing is defined by the Society for Range Management as: "Continued heavy grazing which exceeds the recovery 
capacity of the community and creates a deteriorated range." iii Heavy grazing does come with some risk. If it continues for too long, occurs too often on too large of an area, at critical times for plants or animals, or just prior to weather extremes on exposed soils, it can be very risky. Alternately, infrequent heavy utilization might do no harm. It might, in fact, be ecologically desirable at times. ${ }^{9}$ Well-planned, heavy grazing can help achieve wildland fire fuel or invasive plant reduction goals in targeted-grazing projects. ${ }^{15}$ Properly applied as one of several sources of information, observation and measurement of grazing utilization is one of the key risk-mitigation tools in range management. Finally, as observed in this study, heavy seasonal grazing did not result in exceeding end-of-season utilization levels as specified in the grazing lease. However, recent weather records indicate that there is an approximately $50 \%$ risk of doing so in any given year. This practice should be applied judiciously or factored into future planning for a given pasture when it occurs inadvertently. Site conditions (cover, slope, vegetation) were such that risk of erosion or forage loss was low to moderate if adequate ground cover exists. Recent management (light, infrequent use) had provided for good plant and litter cover to reduce these risks. Long-term or more frequent heavy utilization will increase these risks and would likely contribute to negative ecological and production trends. So, for a given site, the cost-to-benefit ratio of heavy seasonal grazing should be evaluated within the context of: 1) site conditions, 2) "expected" variation in weather, 3) timing within the growing season, and 4) current and historical management.

\section{References}

1. Smith, L., G. Rule, J. Dyess, W. Meyer, S. Barker, C. B. Lane, S. M. Williams, J. L. Maynard, D. Bell, D. StewARt, And A. Coulloudon. 2012. Chapter 40. Utilization. In: Smith, L., G. Rule, J. Dyess, W. Meyer, S. Barker, C. B. Lane, S. M. Williams, J. L. Maynard, D. Bell, D. Stewart, And A. Coulloudon [EDs.]. Guide to rangeland monitoring and assessment: basic concepts for collecting, interpreting and use of rangeland data for management planning and decisions. Tucson, AZ, USA: Arizona Grazinglands Conservation Association. p. 151-161.

2. United States Drought Monitor. 2012. Available at: http://droughtmonitor.unl.edu/. Accessed 26 June 2012.

3. Miller, G., N. Ambos, P. Boness, D. Reyher, G. Robertson, K. Scalzone, R. Steinke, and T. Subirge. 1995. Terrestrial ecosystem survey of the Coconino National Forest. Albuquerque, NM, USA: US Department of Agriculture Forest Service, Southwest Region. 405 p.

4. Steel, R. G. D., And J. H. Torrie. 1980. Principles and procedures of statistics: a biometrical approach. New York, NY, USA: McGraw-Hill Book Co. 633 p.

iii Definition taken from http://globalrangelands.org/rangelandswest.
5. USDa National Resources Conservation Service Plant Materials Program. 2002. Plant fact sheet: western wheatgrass, Pascopyrum smithii (Rydb.) A. Love. Available at: http:// plants.usda.gov/java/. Accessed 23 December 2013.

6. Tolleson, D. R. 2013. Strategic drought scenario planning. Arizona Cattlelog 67(4):9, 12-14.

7. Knutson, C., And T. Haigh. 2013. A drought-planning methodology for ranchers in the Great Plains. Rangelands 35:27-33.

8. McNaughton, S. J., and F. F. Banyikwa. 1995. Chapter 3. Plant communities and herbivory. In: A. R. E Sinclair and P. Arcese [EDs.]. Serengeti II: Dynamics, management, and conservation of an ecosystem. Chicago, IL, USA: University of Chicago Press. p. 49-70.

9. Frank, D. A., S. J. McNaughton, and B. Tracy. 1998. The ecology of the earth's grazing ecosystems. Bioscience 48:513-521.

10. Gunderson, L. H. 2000. Ecological resilience-in theory and application. Annual Review of Ecology and Systematics 31:425439

11. Tolleson, D., L. Halstead, L. Howery, D. Schafer, S. Prince, And K. Banik. 2012. The effects of a rotational cattle grazing system on elk diets in Arizona piñon-juniper rangeland. Rangelands 34:19-25.

12. Smith, L., G. Ruyle, J. Maynard, S. Barker, W. Meyer, D. Stewart, B. Coulloudon, S. Williams, and J. Dyess. 2007. Principles of obtaining and interpreting utilization data on rangelands. Tucson, AZ, USA: University of Arizona College of Agriculture and Life Sciences. Report AZ1375. Available at: http://cals.arizona.edu/pubs/natresources/az1375.pdf. Accessed 23 December 2013.

13. Heitschmidt, R., K. D. Sanders, E. L. Smith, W. A. Layсоск, G. A. Rasmussen, Q. D. Skinner, F. C. Hall, R. Lindenmuth, L. W. Van Tassell, J. W. Richardson, R. R. Fletcher, G. W. Borden, T. R. Harris, D. T. Taylor, B. R. Moline, And W. C. Krueger. 1998. Stubble height and utilization measurements: uses and misuses. Oregon State University Extension. SB 682-E. Available at: http://extension. oregonstate.edu/catalog/html/sb/sb682-e/\#2. Accessed 23 December 2013.

14. Meen, A. 2006.The effects of utilization levels on dietary quality of four forage species on the Arizona Strip. In: J. Sprinkle [ED.]. Range Livestock Nutrition School, Conference Proceedings. Tucson, AZ, USA: Arizona Cooperative Extension. $11 \mathrm{p}$.

15. Launchbaugh, K., and J. Walker. 2006. Chapter 1. Targeted grazing-a new paradigm for livestock management. In: K. Launchbaugh and J. Walker [EDs.]. Targeted grazing: a natural approach to vegetation management and landscape enhancement. Englewood, CO, USA. American Sheep Industry Association. p. 2-9.

Author is Associate Extension Specialist/Research Scientist, $V$ Bar V Ranch, University of Arizona, Rimrock, AZ 86335, USA, dougt@cals.arizona.edu. 